\title{
Accessibility of Sewage Treatment Plants - Benefits and Limitations Associated with Their Location Requirements
}

\author{
Agnieszka Wójtowicz-Wróbel ${ }^{1 *}$ \\ ${ }^{1}$ Facutly of Architecture, Cracow University of Technology, 31-155 Krakow, Poland
}

\begin{abstract}
Due to their specifics, municipal sewage treatment plants have highly specific location requirements. It is, without a doubt, a limitation in relation to the possibility of using these types of plants within an urban structure. On the other hand, in modern, intensively developing cities and the more and more intense incorporation of external areas into - sensu stricto - urban tissue, accessibility and a potentially attractive riverside location create new opportunities. They support new technological solutions that lessen the possible negative impact of such structures. The goal of this article is to highlight which characteristics related to location and other factors are responsible for the possibility of attractively incorporating sewage treatment plants into an urban structure, and which characteristics cause these structures to be excluded from opportunities enabling their wider spatial employment. Accessibility studies, as well as analyses of other elements will be performed using the comparative analysis method, focusing on a selection of examples of sewage treatment plants in large Polish cities. Conclusions about location conditions will be drawn on the basis of the study, which can serve to perform comparative analyses both in cases of sewage treatment plants in other cities, as well as other municipal technical infrastructure plants, whose location is dependent on their function.
\end{abstract}

\section{Introduction}

Municipal engineering infrastructure, in a period of changes in the field of both technology and new pro-environmental efforts, creates new opportunities, but also sets new constraints in place. Nearly thirty years after the transformation of the country's economic policy and a departure from a central distribution system, as well as fourteen years after Poland's accession into the structures of the European Union, we can observe an increase in the awareness of residents concerning matters of environmental protection, as well as a change in the policy of the state in terms of pro-environmental efforts. These transformations are imposed by Poland's membership in European Union structures on the one hand, while on the other they are - generally speaking - caused by a greater awareness among society concerning the protection of resources both for said society, as well as for future

\footnotetext{
*Corresponding author: awojtowicz@.pk.edu.pl
} 
generations. One of the elements of a city's municipal engineering infrastructure are sewage treatment plants and water purification stations, which, along with linear elements, constitute the water supply and sewerage systems of cities. Technological development on the global scale, as well as the possibility of obtaining financial support from European Union structures, have led to a situation in which Poland, as well as other member states, have found themselves with an opportunity to technically and technologically improve their engineering infrastructure. New technological solutions and external financing provide new possibilities. Sewage treatment plants, due to their technical conditions, possess strictly defined placement requirements. Such structures have most often been placed outside of cities, however, due to the intensifying processes of urbanisation, we can observe that treatment plants that were once located far from urban structures have currently found themselves in intensively expanding suburban zones, and those placed on the shores of rivers are often an element along a bicycle or walking path. New technologies, both concerning technical (reducing inconvenience associated with their smell) and visual matters, provide an opportunity for these types of structures to become visually attractive elements of urban and suburban spaces.

Visual matters, as well as the spatial reception of sewage treatment plants in a social perspective is, without a doubt, essential - however, we should ask the question whether direct accessibility is necessary, and if so, then for what reason? Undoubtedly, the inclusion of this type of architecture in municipal social efforts towards furthering the broadly understood idea of environmental protection is a positive development and is putting its potential to good use. The possibility of not only externally perceiving, but also somewhat learning technological processes (at a level at which it is possible for, for instance, the typical city resident who is not a specialist in the field of water treatment and purification) is a beneficial effort. This is quite significant both in the education of children and the shaping their pro-environmental attitudes, as well as in the broadly understood increasing of the ecological awareness of society. Direct educational actions, performed somewhat onsite, have - in the public eye - a greater force of influence than theory or the idea of transferring knowledge "without direct experience". The opening of sewage treatment plants adapted to such a form of social participation will provide the possibility of increasing awareness concerning ecological matters, and - first and foremost - making it possible for people to realise just how great the significance of clean water is to the preservation of the natural environment, not only to society directly, but to the direct and indirect protection of the natural environment.

The research reported on in this article is being performed as a part of a cycle concerning structures which fulfil new pro-environmental engineering functions within cities. The analyses refer to two groups of structures: thermal waste processing plants and structures associated with the treatment of water: sewage treatment plants or water purification plants. The scheme of the research that is being conducted has been presented in the form of a matrix structure in table 1 (cf. [1]). The research focuses on five groups:

- social problems,

- architectural problems,

- problems concerning the placement and accessibility of structures,

- spatial relations, particularly referring to urban structures,

- technical problems.

Currently only the research focusing on thermal waste processing plants has been published. 
Table 1. Scheme of the research being performed using the structure of a matrix.

Original work, 2017

\begin{tabular}{|l|l|l|l|l|l|}
\hline & Social & Architecture & $\begin{array}{r}\text { Locations/ } \\
\text { Accessibility }\end{array}$ & $\begin{array}{c}\text { Urban } \\
\text { Relations }\end{array}$ & $\begin{array}{c}\text { Technical } \\
\text { Issues }\end{array}$ \\
\hline $\begin{array}{l}\text { Thermal } \\
\text { Waste } \\
\text { Processing } \\
\text { Plants }\end{array}$ & S/TWPP & A/TWPP & L/TWPP & U/TWPP & T/TWPP \\
\hline $\begin{array}{l}\text { Wastewater } \\
\text { Treatment } \\
\text { Plant }\end{array}$ & S/WTP & A/WTP & $\underline{\text { L/WTP }}$ & U/WTP & T/WTP \\
\hline
\end{tabular}

\section{Analysis of the accessibility of selected sewage treatment plants located in Polish cities}

Structures of an industrial character are the subject of numerous scientific publications that have investigated them from the perspective of the space of the city, to which we can include an entire spectrum of research - from studies concerning the urban regeneration of post-industrial areas and their adaptation to new urban functions [2], [3], to studies on new forms of industrial zones [4], [5]. Sewage treatment plants are often located in industrial zones, although as a subject of research they are most often analysed from a technological, technical or legal point of view [6], [7]. On the other hand, as it has already been mentioned, due to their placement requirements, sewage treatment plants are being located in riverside areas, often attractive in terms of nature and the landscape, or which are in the vicinity of pedestrian paths or bicycle trails on the outskirts of cities. Due to the increasing ecological awareness of city residents, sewage treatment plants can also, to an extent, perform educational functions: educational trails or so-called 'open days' are being organised in these plants. One of the factors which influence the success of such proenvironmental initiatives in sewage treatment plants is their accessibility. An accessibility analysis was performed on thirteen plants, located in nine Polish cities (Białystok, Bydgoszcz, Gdańsk, Konin, Kraków, Poznań, Reszów, Szczecin, Warsaw)-see tab.2 and 3.

The selection of the cities listed above was dictated by the cohesiveness of the research cycle, as these are also cities which feature pro-environmental thermal municipal waste processing plants. Similar research was performed by the author in reference to thermal municipal waste processing plants [8]. The accessibility of sewage treatment plants was measured along a route from the plant to the centre of the given city. The accessibility was analysed using a passenger car and means of public transport (table 2), as well as a bicycle, in addition to measuring the time needed to reach the destination on foot (table 3 ). The main transfer point (a train or bus station) was chosen as the central point in each city. This made it possible to viably compare the results of the study obtained using different modes of transport. The accessibility was measured in two time groups: during the most intensive traffic load on the transport network (between the hours of 8:00 and 9:00, as well as between 16:00 and 17:00), which are the hours of the most intensive commuting to and from work, as well as during the lowest intensity of the traffic load on the transport network of a city (between 24:00 and 1:00). Bicycle accessibility, as well as pedestrian accessibility, were measured once (between 8:00 and 9:00), as these form of transport are not significantly affected by the load on the transport network. 
Table 2. Selected municipal engineering infrastructure facilities focusing on sewage treatment accessibility using public and private transport during the periods of the highest and lowest traffic load on the transport network, original work, 2018.

\begin{tabular}{|c|c|c|c|c|}
\hline \multirow{2}{*}{ City - name of plant } & \multicolumn{2}{|c|}{$\begin{array}{c}\text { Car } \\
\text { accessibility (min.): }\end{array}$} & \multicolumn{2}{|c|}{$\begin{array}{c}\text { Public transport } \\
\text { accessibility (min.): }\end{array}$} \\
\hline & $\begin{array}{c}\text { Highest } \\
\text { traffic load }\end{array}$ & $\begin{array}{c}\text { Lowest } \\
\text { traffic load }\end{array}$ & $\begin{array}{c}\text { Highest } \\
\text { traffic load }\end{array}$ & $\begin{array}{c}\text { Lowest } \\
\text { traffic load }\end{array}$ \\
\hline $\begin{array}{l}\text { Białystok - Białystok Waterworks } \\
\text { Sewage Treatment Plant }\end{array}$ & $\mathrm{C}$ & $\mathrm{B}$ & $\mathrm{C}$ & $\mathrm{D}^{* *}$ \\
\hline $\begin{array}{l}\text { Bydgoszcz - Fordon Sewage } \\
\text { Treatment Plant }\end{array}$ & $\mathrm{D}$ & $\mathrm{C}$ & $\bullet$ & $\bullet$ \\
\hline $\begin{array}{l}\text { Gdańsk - Gdańsk East Sewage } \\
\text { Treatment Plant }\end{array}$ & $\mathrm{C}$ & B & $\bullet$ & $\bullet$ \\
\hline $\begin{array}{l}\text { * Konin - „Right Bank” Sewage } \\
\text { Treatment Plant }\end{array}$ & $\mathrm{A}$ & $\mathrm{A}$ & $\bullet$ & $\bullet$ \\
\hline $\begin{array}{l}\text { * Konin - „Left Bank” Sewage } \\
\text { Treatment Plant }\end{array}$ & $\mathrm{A}$ & A & $\bullet$ & $\bullet$ \\
\hline $\begin{array}{l}\text { Kraków - „Płaszów” Sewage } \\
\text { Treatment Plant }\end{array}$ & $\mathrm{D}$ & B & $\mathrm{D}$ & $\mathrm{E}^{* *}$ \\
\hline $\begin{array}{l}\text { Kraków - „Kujawy” Sewage } \\
\text { Treatment Plant }\end{array}$ & $\mathrm{D}$ & $\mathrm{C}$ & $\bullet$ & $\bullet$ \\
\hline $\begin{array}{l}\text { Poznań - Left Bank Sewage } \\
\text { Treatment Plant }\end{array}$ & $\mathrm{C}$ & B & $\mathrm{C}$ & $\mathrm{D}^{* *}$ \\
\hline $\begin{array}{l}\text { Rzeszów - Sewage Treatment } \\
\text { Plant of the Municipal Water } \\
\text { Supply and Sewerage Company } \\
\text { in Rzeszów }\end{array}$ & A & A & $\bullet$ & $\bullet$ \\
\hline $\begin{array}{l}\text { Szczecin - „Pomorzany” Sewage } \\
\text { Treatment Plant }\end{array}$ & $\mathrm{A}$ & A & A & $\mathrm{A}$ \\
\hline $\begin{array}{l}\text { Szczecin - „Zdroje’ Sewage } \\
\text { Treatment Plant }\end{array}$ & B & B & $\mathrm{C}$ & $\mathrm{D}$ \\
\hline $\begin{array}{l}\text { Warsaw - „Czajka” Sewage } \\
\text { Treatment Plant }\end{array}$ & $\mathrm{C}$ & $\mathrm{C}$ & $\mathrm{D}$ & $\mathrm{E}$ \\
\hline $\begin{array}{l}\text { Warsaw - „Południe” Sewage } \\
\text { Treatment Plant }\end{array}$ & $\mathrm{B}$ & $\mathrm{C}$ & $\mathrm{C}$ & $\mathrm{E}$ \\
\hline
\end{tabular}

$\mathrm{A} / \mathrm{B} / \mathrm{C} / \mathrm{D} / \mathrm{E}$ - level of the accessibility of sewage treatment plants, arranged in descending order, - no accessibility using the given mode of transportation, $* *$ - differences in accessibility associated with the adopted scale, $*$ - medium-sized city 
Table 3. Selected municipal engineering infrastructure facilities focusing on sewage treatment pedestrian accessibility and bicycle accessibility, original work, 2018

\begin{tabular}{|c|c|c|}
\hline City - name of plant & $\begin{array}{c}\text { Bicycle } \\
\text { accessibility } \\
\text { (min.) } \\
\end{array}$ & $\begin{array}{l}\text { Pedestrian } \\
\text { accessibility } \\
\text { (min.) } \\
\end{array}$ \\
\hline $\begin{array}{l}\text { Białystok - Białystok Waterworks Sewage } \\
\text { Treatment Plant }\end{array}$ & $\mathrm{C}$ & $\mathrm{E}$ \\
\hline Bydgoszcz - Fordon Sewage Treatment Plant & $\mathrm{E}$ & $\mathrm{E}$ \\
\hline Gdańsk - Gdańsk East Sewage Treatment Plant & $\mathrm{C}$ & $\mathrm{E}$ \\
\hline *Konin - „Right Bank” Sewage Treatment Plant & A & $\mathrm{D}$ \\
\hline * Konin - „Left Bank” Sewage Treatment Plant & A & $\mathrm{D}$ \\
\hline Kraków - „Płaszów” Sewage Treatment Plant & $\mathrm{C}$ & $\mathrm{E}$ \\
\hline Kraków - „Kujawy” Sewage Treatment Plant & $\mathrm{E}$ & $\mathrm{E}$ \\
\hline Poznań - Left Bank Sewage Treatment Plant & $\mathrm{B}$ & $\mathrm{E}$ \\
\hline $\begin{array}{l}\text { Rzeszów - Sewage Treatment Plant of the } \\
\text { Municipal Water Supply and Sewerage Company } \\
\text { in Rzeszów }\end{array}$ & $\mathrm{B}$ & $\mathrm{E}$ \\
\hline Szczecin - „Pomorzany” Sewage Treatment Plant & A & $\mathrm{D}$ \\
\hline Szczecin - „Zdroje' Sewage Treatment Plant & $\mathrm{C}$ & $\mathrm{E}$ \\
\hline Warsaw - „Czajka” Sewage Treatment Plant & $\mathrm{E}$ & $\mathrm{E}$ \\
\hline Warsaw - „Południe” Sewage Treatment Plant & $\mathrm{D}$ & $\mathrm{E}$ \\
\hline
\end{tabular}

$\mathrm{A} / \mathrm{B} / \mathrm{C} / \mathrm{D} / \mathrm{E}$ - level of accessibility of sewage treatment plants, in descending order, ${ }^{*}$ - medium-sized city

In the case of the accessibility analysis performed using an individual mode of transport (a car) and public transport, two averaged scales of accessibility were adopted. These scales were dependent on the time during which the measurements were taken: a different scale 
was adopted for the hours with the highest load placed on the transport network and a different one for the lowest load. For the lowest traffic load on the transport network, this scale was as follows: A (up to 10 minutes) - very good accessibility, B (10-15 minutes) good accessibility, C (15-25 minutes) - passable accessibility, D (25-45 minutes) - poor accessibility, E (over 45 minutes) - very poor accessibility. At the same time, for the hours with the highest traffic load placed on the transport network, the following time values were adopted: $\mathrm{A}$ - up to 15 minutes, $\mathrm{B}-15-30$ minutes, $\mathrm{C}-30-45$ minutes, $\mathrm{D}-45-60$ minutes, $\mathrm{E}-$ in excess of 60 minutes. Due to the fact that travel using public transport and a private mode of transport can take place along the same routes, different time intervals between these two modes of transport were not adopted. Due to the fact that sewage treatment plants are placed in riverside areas and are often placed nearby walking or bicycle trains, the study also included the accessibility of the plants using these two modes of travel (tab. 3). Accessibility using the bicycle as well as pedestrian accessibility was defined on a fivepoint scale. In the case of bicycle accessibility, these were the following intervals: up to 10 minutes (A), 10-20 minutes (B), 20-30 minutes (C), 30-45 minutes (D and in excess of 45 minutes (E). In the case of pedestrian accessibility, the isochrones were much shorter and were adopted as follows: very good accessibility - up to 5 minutes (A), good accessibility (B) 5-10 minutes, average accessibility (C) is a distance travelled in 10-20 minutes, while poor and very poor accessibility were 20-30 minutes (D) and in excess of 30 minutes (E), respectively.

The plants listed in tables 2 and 3 were located - as far as Polish conditions are concerned - in large cities. Konin was the exception here, as its number of inhabitants was 75,5 thousand at the time of carrying out the study and it can be counted among mediumsized cities. This is a deciding factor in matters of accessibility due to the scale of the city, as well as the (primarily) lower traffic loads than in large cities. For this reason Konin has been highlighted in tables 2 and 3 as a city having a different accessibility dynamic than the others, due to its scale.

\section{Discussion and commentary on the results of the research}

Based on the research performed by the author, which covered thirteen different sewage treatment plants in nine Polish cities, it can be observed that there are significant differences both in terms of the accessibility of plants within a given investigated type in relation to cities and in the analyses of a given city in terms of each type of locomotion. Accessibility using the car can be considered good. During the highest traffic load on the transport network, $54 \%$ of the plants were placed in a zone of either good or very good accessibility (A or B category) and, simultaneously, no plant found itself in the very poor accessibility category (E). Accessibility of these types of plants during the time of the lowest traffic load on the transport network turned out to be even better, as almost $70 \%$ of the plants were observed to be in zones of either good or very good accessibility, while the remaining $30 \%$ had an average accessibility. From among the group of all sewage treatment plants, the best accessibility, regardless of the time of day and the associated vehicular traffic intensity, was observed in Konin (the "Left Bank" Sewage Treatment Plant and the "Right Bank" Sewage Treatment Plant), which is the smallest city in the entire listing. This leads to a lower level of transport problems than in other cities. Simultaneously, an analogous rule in reference to the largest city on the list - Warsaw - was not observed. The accessibility of the sewage treatment plants within the capital was around average. Overall, the worst accessibility was registered in Krakow. In the case of two sewage treatment plants, accessibility was registered at a low level (particularly during the time of high traffic load on the city's transport network) despite the fact that such structures were located in two different areas of the city, while one plant (the "Płaszów" Sewage Treatment Plant) 
was located much closer to the centre than the "Kujawy" Sewage Treatment Plant. Regardless, when analysing the accessibility of the plants by car, both during rush hour and outside of it, it can be stated that when using this mode of transport the accessibility of the sewage treatment plants was registered as good. Table 2 also contains an analysis of transport accessibility using public transport, according to the same criteria. This type of accessibility of the analysed plants was observed to be significantly limited. Only $54 \%$ of the plants from the entire list were accessible by public transport, with the accessibility of only a single plant (the "Pomorzany" Sewage Treatment Plant in Szczecin) being classified as very good while the remaining plants had either poor or very poor accessibility (6 plants). However, one interesting characteristic is that accessibility using public transport of all the seven plants was also available during the hours of the lowest traffic intensity (night time). However, the differences in terms of accessibility between rush hour and outside of it mainly resulted from the adopted time intervals in the classification described in the previous chapter (short intervals for analysis outside of rush hour), and not from an increased length of travel. The plants in the case of which transport accessibility between the period with the highest and lowest traffic load was equal. or in the case of which it amounted to only a few minutes, have been highlighted in table 2 .

As mentioned in the previous chapter of the article, because of the placement of sewage treatment plants predominantly in areas of high natural value, featuring significant visual characteristics, as well as in the proximity of bicycle paths and walking trails, due to the possible influence of sewage treatment plants on the visual values of walking areas resulting from this fact, an analysis of the accessibility of these types of structures using both the bicycle, as well as on foot was performed. In the case of travel by bicycle, both good, average and poor accessibility were distributed relatively evenly. The group of plants with a good or very good accessibility, i.e. up to 10 minutes of travel time, included both of the sewage treatment plants located in the smallest of the analysed cities - Konin - as well as plants in Poznań and Rzeszów, in addition to the "Pomorzany" Sewage Treatment Plant, located in Szczecin. The second of Szczecin's sewage treatment plants, "Zdroje", placed in the average accessibility group, i.e. with up to 30 minutes of travel time by bicycle. In this group there were also three other plants: in Białystok, Gdańsk and one of Krakow's plant (the "Płaszów" Sewage Treatment Plant). The group with the poorest accessibility using the mode of transport in question included four plants: the second of Krakow's plants, the plant in Bydgoszcz, as well as two plants providing services to Warsaw's sewerage system. Of note is the fact that, despite describing the plants from the final group as poorly accessible, the travel time between them and the centre of their respective city did not exceed 60 minutes. Using the bicycle as a mode of transport, it is a distance which is in range of those city residents who use it as a form of physical activity. The pedestrian accessibility of sewage treatment plants presented itself altogether differently. Their locations did not make it possible to determine pedestrian accessibility isochrones at a good or average level. Practically all of the structures were observed to have a poor or very poor pedestrian accessibility. Three of them were characterised by an accessibility within the 20-30 minute range, which is an isochrone of viable access for city residents, but that nevertheless is within the lower values. These included the "Pomorzany" Sewage Treatment Plant in Szczecin, as well as the two sewage treatment plants in Konin. The remaining nine plants were located in areas accessible after a minimum of a half-an-hour-long walk. Of note is the fact that among this last group, $80 \%$ of the plants were located within the range of a pedestrian accessibility time of between 1,5 hour to even up to close to four hours. In this case there is no actual pedestrian accessibility to speak of. 


\section{Conclusions and observations}

Due to the increasing necessity to protect the natural environment in which we live, as well as due to the increasing public awareness in this regard, the subject of the placement and accessibility of sewage treatment plants becomes important and topical. The study performed on a group of thirteen sewage treatment plants located in nine Polish cities (in which there were also thermal waste processing plants), made it possible to arrive at the following conclusions and observations:

- A significant part of the sewage treatment plants were located within the range of access by vehicular transport, but only a few were accessible using public modes of transport.

- It can be stated that the sewage treatment plants subjected to the analysis were located in the zone of bicycle accessibility, with only being a few of them within the zone of pedestrian accessibility.

- Good accessibility using one's own mode of transport (a car or a bicycle) is a quality which makes it possible for a fuller inclusion of these types of structures in the urban structure both in spatial and social terms, rather than solely in technological ones. Simultaneously, the relatively poor accessibility of these types of structures using municipal public transport limits the possibilities concerning the use of these plants (poor accessibility for the residents of cities, e.g. during the organisation of open days or in the case of trips that can use a didactic trail).

- Sewage treatment plants, due to their relatively good accessibility and under the condition of adapting them to new, pro-environmental forms of use of an educational character, as well as through improving the quality of their visual aspect, could constitute an important and attractive element of an urban or suburban space.

- To sum up, it can be stated that through improving the accessibility (from the point of view of transport) of these types of facilities and the associated accessibility in terms of making these structures available for, for instance, educational efforts, it is possible to increase the ecological awareness of society, e.g. in terms of presenting just how important clean water is not only to society, but also to the protection and preservation of the natural environment in which we live.

\section{References}

1. B. Podhalański, Technology through scales and its impact: from the metropolitan region to the district's urban form, Urban Planning Architecture \& Design, SGEM 2017, Book 5, 1, 295-302 (2017)

2. Z. Zuziak, Inner cities redevelopment in German metropolises. Part 1: Cologne, Munich, Stuttgart, Technical Transactions, Architecture, 12,191-243 (2011)

3. A. Hrabiec, The areas of strategic intervention in revitalizations places of the CracowMetropolis cities, Technical Transactions, Architecture, 1-A, 135-143 (2011)

4. M. Smętkowski, Rola specjalnych stref ekonomicznych w kształtowaniu struktury przestrzennej przemysłu w Polsce, Prace KOmisji Geografii Przemystu, 10,204-216 (2008)

5. J.Błachut, Special Economic Zones within metropolitan areas - Górny Śląsk (Upper Silesia), Technical Transactions, Architecture, A-5,184-195 (2008)

6. K. Chmielowski, R. Ślizowski, Evaluation of the effectiveness of pollutants' removal in the sewage treatment plant in Tarnów, Infrastructure and Ecology of Rural Areas, 5/2009,137-146 (2009) 
7. A.Walega, K.Chmielowski, S.Satora, Water and wastewater management condition in Poland regarding Water Framework Directive implementation, Infrastruktura $i$ Ekologia Terenów Wiejskich, 4, 57-72 (2009)

8. A. Wójtowicz-Wróbel, Thermal waste processing system structures. Questions of locations and accessibility-Polish experiences, Energy and clean technologies, SGEM 2017, 41/17, 261-268 (2017) 